\title{
INTRODUCTION TO THE FIRST EDITION
}

THE SUBJECT OF THIS STUDY, the Russian fairy tale (volsébnaja skázka), is the most numerous and artistically the most elaborate of the Slavic folktales. Also, as Jirí Polívka, the great Czech folklorist, demonstrates in his comparative studies of the Slavic folktale, its structural and formal complexity has no equivalent in the fairy tales either of Western Europe or of the Eastern, nonSlavic neighbors of Russia. Nonetheless, it is just the archaic features of the Russian fairy tale that are its exclusive national trademark. There are a few historical, cultural, and social factors that lie in the background of this striking folklore phenomenon. To begin with, the verbal art of all the Eastern and Southern Slavic territory, in general, has always been of preponderantly epic character, so that, in contrast to the Slavic West, the narrative genres both in prose and verse were particularly strongly developed in Russian, Bulgarian, and Serbian folklore. Furthermore, since in Russia written literature was, until the seventeenth century, used only for religious themes, ecclesiastic purposes, and the Church Slavonic language, the Russian fairy tale, specifically, could evolve without any literary influence from above. The custom of tale-telling having been practiced among all the social classes, the artistic tools of the narrator became progressively sharpened; the demands of the listener became more and more refined; and the narrative codes of the fairy tale were step by step crystallized under the influence of this social censorship. The art of narration and dramatic presentation, together with a keen sense of the oral epic style, became a characteristic quality of the Russian people.

No wonder then the Russian folktale was reflected in the Russian popular tale of the eighteenth century, left its unmistakable imprint on the sophisticated short story, which was being fashioned at that time in Russia after the Western model, and eventually became the primary source from which the greatest Russian writers of the nineteenth century created the Russian literary language. 
Russian folktales were first collected on a wide scale by $\mathrm{A}$. $\mathrm{N}$. Afanás'ev. His Rússkie naródnye skázki, published in 18551864 , still stands as the basic Russian folktale collection. The mid-century marks also the beginning of the scientific interest in the folktale in Russia. The Russian ethnographers adapted the mythological and the diffusionist approach of the Western schools to the study of their native folklore. And an original, pioneering work was done by the sociologically oriented folklorists who, beginning in the 1860 's, concentrated on the narrator himself and investigated the impact of his creative abilities and of his geographical and social background on the folktale, particularly on the formation of its variants.

The modern Russian studies of the folktale developed in close relation with the new European trends in ethnographic scholarship. When in the 1920's the emphasis was shifted from speculations about origin to the synchronic aspect of the folktale, it was the Aarne-Thompson Index of folktale types that answered the generally felt need for a scientific classification of the common folktale stock. This gigantic achievement of the Finnish-American school launched a new search for a common denominator in the multiformity of the folktale; it inspired new interpretations of the simultaneous occurrence of similar phenomena, and made possible the stating of further specific problems. In Russia, where the Aarne Index of the folktale types was translated and filled out with Russian material, the West European methodological advances coincided with the scholarly offensive of the young formalist school and facilitated its task. The basic tenet of this school was the structural analysis of the literary work. Folklore, owing to its specific features as a collective productits recurrent, conventionalized and stylized structural components, its highly pronounced formula characteristics and the semantic significance it ascribes to the sound, and stylistic patterns -became the principal experimental ground of the formalists. Linguists, literary historians, and ethnographers investigated the narrative technique of the folktale and the prosody of epic folk poetry, of folksongs, proverbs and riddles. In fact, the leading formalist theoretician, Viktor Sklóvskij, began his innovatory studies of prose with the Russian fairy tale.

The author of the present volume, Vladimir Propp, was an outstanding member of the Russian formalist group, and his 
Morphology of the Folktale presents a brilliant example of the orthodox formalist method, applied to the structural analysis of the fairy tale. Operating with a comparatively limited corpus of fairy tales chosen from the Afanás'ev folktale collection, his aim was a description of the fairy tale per se. In his analysis he departs from the smallest narrative units, the motifs; he defines the motifs in terms of their function, that is, in terms of what the dramatis personae do, independently of by whom and in what way the function is fulfilled. He states the number of these functions obligatory for the fairy tale and classifies them according to their significance and position in the course of the narrative. Their sequence is finally the basis of his typology within the genre. He abstracts the compositional pattern that underlies the structure of the fairy tale as a whole and formulates its compositional laws by way of structural signs.

When the Morphology of the Folktale appeared in 1928, the formalist trend was already in a state of crisis in Russia. For this reason it was neither translated outside of Russia, nor were its tenets ever discussed in an international forum. However, it exerted some influence. Thus, for instance, Claude Lévi-Strauss applies and even extends Propp's method in his study of myth and in the interpretation of the meaning of myth from its form and structure.

Almost twenty years later, V. Propp returned once more to the subject of the folktale, but this time from a different point of view. In his IstoriČeskie kórni volsébnoj skázki ("The Historical Roots of the Fairy Tale"), he abandons the strict study of form and structure and deals instead with the affinities that exist between the fairy tale and religion (myth and ritual) and social institutions at different levels of their evolution. A more specific folklore phenomenon is treated by him in a study of ritual laughter where he shows that ritual laughter in the folktale for instance, often understood as an expression of a purely secular fun, is, in fact, ritualistically linked with myth and incantational magic.

\section{REFERENCES}

Andreev, N. Uharatel shazočnyx sjuketov po sisteme Aarne (Leningrad, 1929). Bogatyrev, P. and R. Jakobson. Slavjanskaja filologija $v$ Rossii za gody vojim i revoljucii (Berlin, 1923). 
Erlich, V. Russian Formalism (The Hague, 1955).

Jakobson, R. "Commentary," Russian Fairy Tales (New York, 1945).

Levi-Strauss, C. "Structural Study of Myth," Journal of American Folklore, LXVIII (1955), 428-43.

Nikiforov, A. "K voprosu o morfologið̌eskom izuと̌enii narodnoj skazki," Sbornik Otd. rus. jaz. i slov. Akademii nauk, CI (1928).

Polivka, J. "Slovanské pohádky," I, Prdce Slovanskeho Ustavu, VI (1932).

Propp, V. Morfologija skaxki (Leningrad, 1928).

- "Transformacii volsebnyx skazok," Poetika, IV (1928).

- "Volsebnoe derevo na mogile," Sovetskaja etnografija, Nos. 1-2 (1934).

-. "Ritual'nyj smex v fol'klore," Učenye zapiski Leningradskogo Gos. Universiteta, No. 46. Ser. filol. nauk, vyp. 3 (1939).

—. IstoriCeskie korni voľ̌ebnoj skazki (Leningrad, 1946).

- Russkij geroiceskij èpos (Leningrad, 1955).

Shaftymov, A. Podtika i genezis bylin (Saratov, 1924).

3kl6vikij, V. O teorii prozy (Moscow, 1925); second edition, 1929.

Thompson, Stith. The Types of the Folktale: Antti Aarne's Verzeichnis der Märchentypen, Translated and Enlarged, FF Communications, No. 74 (Helsinki, 1928).

Trubetzk6y, N. “O metrike Castuški," Vërsty, II (Paris, 1927). 